Article

\title{
Cropland Abandonment in South African Smallholder Communal Lands: Land Cover Change (1950-2010) and Farmer Perceptions of Contributing Factors
}

\author{
Dale Blair, Charlie M. Shackleton $\mathbb{D}$ and Penelope J. Mograbi * \\ Department of Environmental Science, Rhodes University, Grahamstown 6139, South Africa; \\ daleblair08@gmail.com (D.B.); C.Shackleton@ru.ac.za (C.M.S.) \\ * Correspondence: Penny.Mograbi@gmail.com; Tel.: +27-46-603-7011
}

Received: 6 August 2018; Accepted: 13 September 2018; Published: 16 October 2018

check for updates

\begin{abstract}
Despite agricultural land abandonment threatening the food security and the livelihoods of smallholder farmers, it is pervasive globally and in developing countries. Yet land abandonment is an understudied aspect of land use change in social-ecological systems. Here we provide more information on this phenomenon by exploring cropland abandonment during 1950-2010 in four former South African 'homelands' - part of the 'Apartheid' era racially-based land allocation programs-characterized by rural, smallholder farmers. Cropland abandonment 1950-2010 was widespread in all surveyed sites (KwaZulu: $0.08 \%$ year $^{-1}$, Transkei: $0.13 \%$ year $^{-1}$, Lebowa: $0.23 \%$ year $^{-1}$, Venda: $0.28 \%$ year $^{-1}$ ), with rates peaking between 1970 and 1990 , with concomitant increases (up to $0.16 \%$ year ${ }^{-1}$ ) of woody vegetation cover at the expense of grassland cover. Active and past farmers attributed cropland abandonment to a lack of draught power, rainfall variability and droughts, and a more modernized youth disinclined to living a marginal agrarian lifestyle. We discuss the potential social and ecological implications of abandoned croplands at the local and regional scales, as the deagrarianization trend is unlikely to abate considering the failure of current South African national agricultural incentives.
\end{abstract}

Keywords: agricultural land abandonment; bush encroachment; deagrarianization; homelands; old fields; social-ecological systems; rural farmers

\section{Introduction}

Future food production in sub-Saharan Africa needs to increase threefold [1] to match the needs of the projected population of 1.5 billion people by 2050 [2]. In most countries the food production sector is dominated by smallholder farmers, occupying approximately $30 \%$ of agricultural land (with notable exceptions such as South Africa) and providing more than half of global food calories, as well as $70 \%$ of the calories in the smallholder-dominated developing countries [3]. Most smallholder farmers in sub-Saharan Africa practice low-input/low-yield subsistence agriculture because of limited assets, including one or more of finances, labor and land. This constrains their ability to access markets or compete with market prices, as a result of both demand and supply-side factors [4], including access to inputs and credit systems [2,5]. Consequently, many regions and households are food insecure [6]. In reality, before the needs of a burgeoning population can be met, developing countries need to address the current "double burden of malnutrition" from both undernourishment and overnutrition (from dietary transitions) [7], and food production is key to solving these challenges.

Farming is not just about food production, as it also contributes to land-based livelihoods of rural households by improving self-provisioning capacity, providing non-food goods, monetary and 
non-monetary services, a buffer from shocks, livelihood diversification, a sense of place, identity and wellbeing, and security from the knowledge of having land and a home on that land [8,9]. Thus, there are many reasons to support small-scale farmers to promote reductions in food insecurity, poverty and household vulnerability, whilst simultaneously promoting regional or national food production, economies, and sustainable land use. Sub-Saharan Africa also has enormous potential to improve smallholder farming yields as most agricultural land has underrealized potential productivity [10], and smallholder productivity would need to double by 2030 to realize the United Nations Sustainable Development goals on poverty, food security and environmental sustainability [11].

Despite the clear need for increased agricultural engagement and productivity, abandonment of agricultural land is increasing both globally [12-14] and within sub-Saharan Africa $[15,16]$. Definitions of agricultural land abandonment vary according to the approach (e.g., social, administrative), or whether qualitative (e.g., land condition) or quantitative (e.g., number of years abandoned) data are used [17]. Bryceson's [15] 'deagrarianization' describes a holistic process that constitutes changes in occupation, redirection of income-earning, social identification, and spatial relocation of rural inhabitants away from strictly agriculture-based livelihoods. The difficulties in defining cropland abandonment speak to the multiscale, interconnectedness of the natural, economic and social aspects of agricultural activities. Essentially, agricultural land abandonment is the cessation of agricultural activities, but it is a complex process that may occur simultaneously with farmland clearing [17], or with interrupted and short periods of crop farming [9]. Cropland abandonment occurs at varying intensities and is often a non-linear process with possible multiple alternative trajectories [18], reflecting the emergent properties of complex local and global feedbacks in social-ecological systems [19]. Cropland abandonment as a component of deagrarianization should not be confused with rotational systems of cropland resting implemented to restore soil fertility or temporary withdrawal from agricultural production due to adverse conditions such a drought or transient lack of labor or inputs. Here, we define 'cropland abandonment' as land that is no longer farmed for economic, social or other reasons.

The socio-economic consequences of cropland abandonment have been comprehensively covered in rural studies. At the household scale they include a reduction in self-provisioning capacity and income [8], reduced dietary diversity, and increased food insecurity, vulnerability and poverty [20]. Following the expanded definition of agricultural contribution to rural livelihoods from Shackleton et al. [8], there is also a reduced safety-net capacity to withstand shocks such as death or unemployment of the household breadwinner. Farming households also have a more diversified income [21]. At the community scale cropland abandonment contributes to a loss of the traditional landscape [18], erosion of cultural heritage, lifestyle, identity and values [22], and a reduction in social cohesion as unemployed and idle youth may resort to criminal activity [23]. At a regional scale, there is reduced agricultural supply to markets, as well as reduced demand for the inputs and support services associated with agricultural production and markets. Additionally, the displacement of rural livelihoods can place increased pressure on urban centers to provide work for rural migrants [18]. Conversely, cropland abandonment may release the time, labor and associated financial costs of crop farming for individuals, households and communities, who can then create alternative income opportunities.

The ecological repercussions of cropland abandonment depend strongly on the pre-existing biotic and abiotic context, the historical agricultural activity, type, duration and intensity [13]. Inconsistent results from similar geographic regions are influenced by the research framing, and whether the research was focused on the pre- or post-abandonment period [24]. Although the directions of change in variables of interest may vary, there is consensus that cropland abandonment alters albedo, habitats, carbon sequestration, ecosystem services, hydrological regimes, soil fertility, and biodiversity, amongst others (see reviews: [18,25-27]). Abandoned croplands are particularly susceptible to invasive species and fire [13]. The ecological consequences, and subsequent management options, of cropland abandonment have received exhaustive attention in Western Europe (e.g., $[28,29])$ but research in 
developing countries is limited, albeit increasing (e.g., [16,30,31]). Cropland abandonment is a globally integrated phenomenon as cropland abandonment in one region may cause cropland clearing in another [32].

Just as the consequences of cropland abandonment are context-specific and span multiple spheres at multiple scales, so too do the causes. Cropland abandonment occurs on less agriculturally productive and/or remote areas (e.g., steep mountain slopes and marginal land: [33,34]), as well as on productive and/or accessible land $[35,36]$. Cropland abandonment is influenced by climatic extremes (such as droughts and floods), elevation, slope, aspect, and edaphic factors (soil fertility, soil depth, erodibility) [25]. In turn, soil erosion and soil fertility declines may be a consequence of land management, such as heavy grazing or exhaustion of soil nutrients. Socio-economic factors include rural outmigration, industrialization, local and global market forces, rural-urban connections [18,37], farm and farmer characteristics, and market access [25]. Increases in cropland abandonment may also be affected by slowing population growth and/or agricultural intensification, and by improving efficiency and yields, which releases land from agricultural production [38]. These factors may interact within and across scales, as well as between the biophysical and socio-economic realms, creating synergies and feedbacks [27].

The interactions between factors associated with cropland abandonment are particularly 'wicked' in South Africa, with the addition of historical, socio-political inequalities stemming from the former 'Apartheid' era, enacted through race-based land tenure rights, relocation and expropriation. The Apartheid government relocated black South Africans into designated areas, known as 'homelands', under the Natives Land Act of 1913, effectively creating laborers from peasant farmers [39]. These former homelands are characterized by high human and livestock population densities [40]. Homeland households are largely dependent on migrant labor remittances and state welfare (known as 'social grants'), with farming making varied contributions depending on local biophysical context and household assets. Although cropland abandonment is not a new phenomenon in southern Africa (e.g., [16,41]), the degree and extent of cropland abandonment and deagrarianization in South Africa has increased with strengthening rural-urban connections [9,42], globalization, modernization [43], increasingly diversified household incomes and activities [44], and changes to 'agrarian' identities [9]. In an Eastern Cape study, Shackleton and Luckert [43] suggest that short-term 'shocks' that may affect cropland abandonment-such as loss of a breadwinner through death or unemployment-are themselves a result of 'background' contextual factors. These include interrelated themes of change in household composition and assets, the systemic effects of HIV/AIDS, altered rural demographics and rural values, erosion of social and cultural capital, low education levels, and urbanization [43]. Thus, households are increasingly unable or unwilling to engage in agrarian activities and rely heavily on state social grants and unstable labor remittances, resulting in increased vulnerability of rural communities to global socio-economic forces [43]. Studies in rural areas have shown a reduction in farmed arable lands and an increase in smaller home gardens, a reduction in livestock ownership, and an increase in wage-based livelihoods $[9,16,43,45,46]$. In South African communal lands, land does not automatically revert back to the traditional tribal authority for reallocation if it is 'unused' (i.e., not cultivated), but remains zoned for use by the family. Note that the term 'croplands' in a rural, smallholder farmer context may include both large farmed fields as well as small, home, food gardens. Here we use 'croplands' to refer to only large farmed fields.

The few studies of cropland abandonment in South Africa have reported widely varying rates between sites. For example, a Transkei village (Willowvale) had a cropland abandonment rate of $0.1 \%$ per annum between 1961 and 2009 [16] while a study in two villages near Lebowa (Mahlambandlovu and Monyamane) recorded a 1.6-2.6\% loss in agricultural land between 1989 and 2000 [47]. Cropland abandonment rates may also vary over time, such as that reported in a Transkei village (Nompa) 1942-1962 (3.4\% decrease) and 1962-1982 (49.2\% decrease) [48]. The few studies that report change in smallholder agricultural activities have focused on localized sites, used different methodologies, across a variety of time frames, confounding the understanding of the extent and variation in 
agricultural land abandonment e.g., [9,49-53]. Before adequate policy and management response to agricultural land abandonment can be formulated, there is need for a broadscale understanding of agricultural disengagement in communal areas, as well as an understanding of the variation in this phenomenon within and between sites. Here we explore the long-term change in, and proximal 'factors' (sensu [54]) associated with, cropland abandonment in South African communal lands. Specifically, we ask: (i) what are the changes in active and abandoned croplands in four former South African 'homelands' between 1950 and 2010? (ii) Are there differences in household characteristics between self-identified active and past farmers? (iii) What are farmers' perceptions of the factors influencing engagement with agriculture? (iv) What are their perceptions of the use of old fields for non-crop farming purposes?

\section{Materials and Methods}

\subsection{Study Site}

We investigated cropland abandonment rates in four former Apartheid homelands: Transkei (now part of the Eastern Cape province), KwaZulu (now part of the KwaZulu-Natal province), Lebowa (now part of the Limpopo province), and Venda (now part of the Limpopo province) (Figure 1). These traditional, communal areas are in the eastern, warmer and more mesic ( $>650 \mathrm{~mm}$ p.a.) (Table 1$)$, side of South Africa which is more conducive to arable agriculture than the arid west. The sites were all densely populated with high levels of unemployment (Table 1). All sites have land use combinations of agriculture and ranching, whilst mining also occurs in Lebowa and Venda. Vegetation types were combinations of grasslands, forests and savannas, although coastal forest was present in KwaZulu and Transkei (Table 1). Transkei also contained thicket and there were no grasslands in Venda. This study adopted a mixed-methods approach to assess long-term land cover change using repeat, aerial imagery and interviews on historical agricultural land use change and perceptions of agricultural engagement. Remotely-sensed land cover change analysis was conducted in all four sites, while interviews were conducted in KwaZulu and Transkei (Figure 1), due to time and logistic constraints.

Table 1. Climate, demographic and land use information for Transkei, KwaZulu, Lebowa, and Venda.

\begin{tabular}{|c|c|c|c|c|}
\hline Variable & Transkei & KwaZulu & Lebowa & Venda \\
\hline Area $\left(\mathrm{km}^{2}\right)$ & 44,424 & 36,067 & 22,223 & 6493 \\
\hline Mean annual rainfall $(\mathrm{mm})^{1}$ & 693 & 844 & 626 & 642 \\
\hline $\begin{array}{l}\text { Mean temp. } \\
\max \left({ }^{\circ} \mathrm{C}\right)^{1}\end{array}$ & 21.7 & 23.1 & 23.5 & 22.7 \\
\hline $\min \left({ }^{\circ} \mathrm{C}\right)^{1}$ & 12.2 & 16.0 & 12.9 & 11.1 \\
\hline $\begin{array}{l}\text { Population density } \\
\left(\text { people } \mathrm{km}^{-2}\right)^{2}\end{array}$ & 106 & 275 & 196 & 220 \\
\hline $\begin{array}{l}\text { Average household size } \\
\text { (people per household) }^{2}\end{array}$ & 3.9 & 4.0 & 3.8 & 3.8 \\
\hline Unemployment rate $(\%)^{2}$ & 28.0 & 20.0 & 30.0 & 18.0 \\
\hline Vegetation types ${ }^{3}$ & $\begin{array}{l}\text { Albany Thicket; } \\
\text { Forest; Grassland; } \\
\text { Indian Ocean } \\
\text { Coastal Belt; } \\
\text { Savanna }\end{array}$ & $\begin{array}{l}\text { Forest; Grassland; } \\
\text { Indian Ocean } \\
\text { Coastal Belt; } \\
\text { Savanna }\end{array}$ & $\begin{array}{l}\text { Forest; } \\
\text { Grassland } \\
\text { Savanna }\end{array}$ & $\begin{array}{l}\text { Forest; } \\
\text { Savanna }\end{array}$ \\
\hline Geology ${ }^{4}$ & $\begin{array}{c}\text { Dwyka and } \\
\text { Beaufort tillites, } \\
\text { sandstones, and } \\
\text { shales }\end{array}$ & $\begin{array}{l}\text { Dwyka, Ecca, and } \\
\text { Maputaland tillites, } \\
\text { sandstones, and } \\
\text { shales }\end{array}$ & $\begin{array}{l}\text { Pretoria and } \\
\text { Blouberg } \\
\text { siltstones and } \\
\text { sandstones }\end{array}$ & $\begin{array}{l}\text { Lebombo } \\
\text { basalts and } \\
\text { rhyolites }\end{array}$ \\
\hline
\end{tabular}




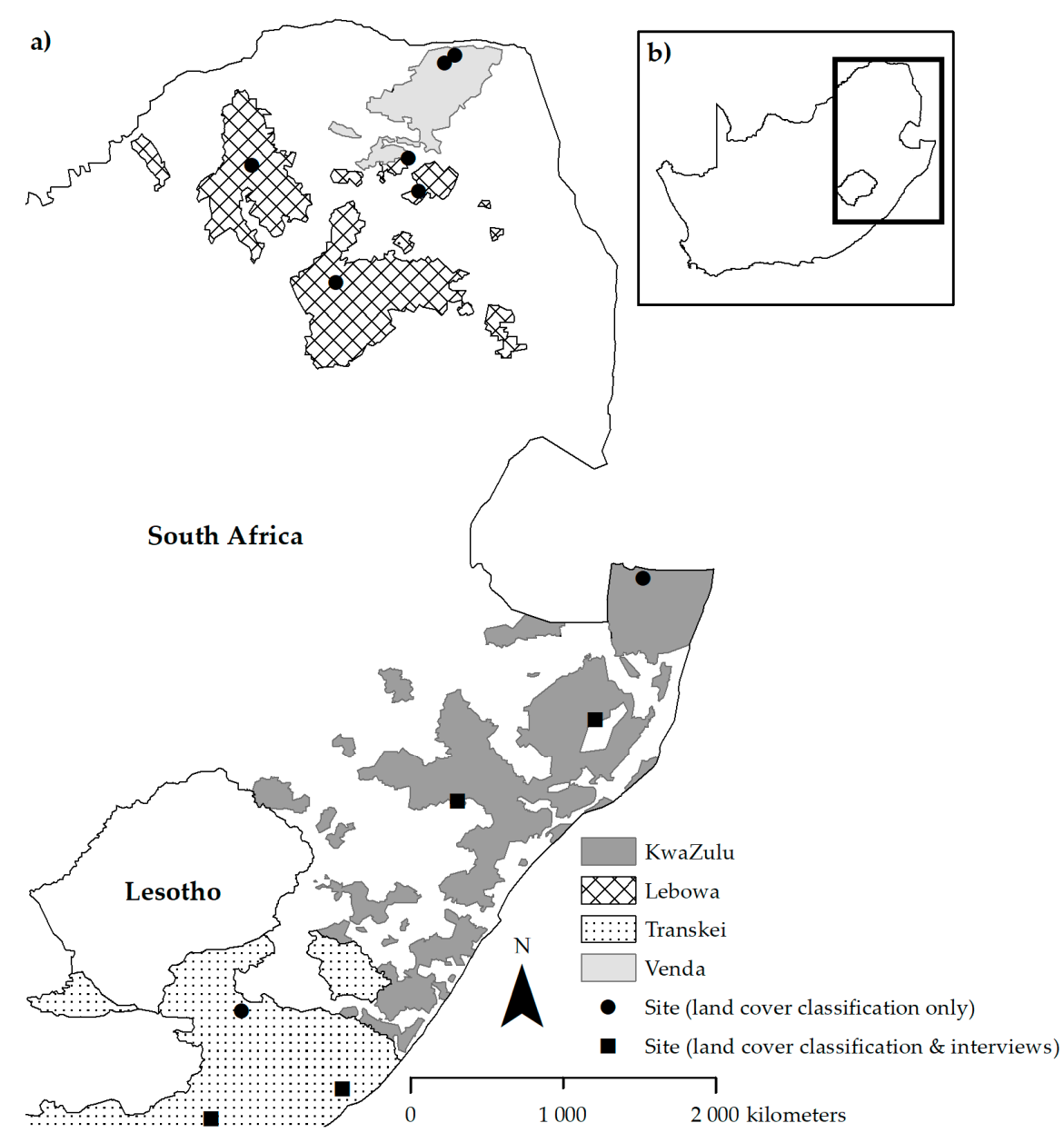

Figure 1. (a) The locations of study sites in four former homelands, including land cover survey sites and sites with combined land cover and interview-based surveys. (b) The inset map shows the location of the eastern former homelands within South Africa.

\subsection{Land Cover Change (1950s-2010s)}

Aerial photographs from three randomly selected sites in each of the four former homelands were acquired from the South African National Geo-Spatial Information (www.ngi.gov.za) for the 1950s, 1970s, 1990s and 2010s. Images were captured on analogue cameras from the 1950s to 1990s at scales ranging from 1:30 000 to 1:50 000 (site- and decade-dependent) and scanned at high-resolution (900 dpi). The 2010 aerial photographs were digital images with $0.5 \mathrm{~m}$ resolution. Although the image resolution and quality varied between sites and years, there was sufficient detail to classify vegetation cover, small buildings, past and present field boundaries, and isolated trees within fields.

A $20 \mathrm{~km} \times 20 \mathrm{~km}$ grid was placed over each image and 900 randomly selected $50 \mathrm{~m} \times 50 \mathrm{~m}$ cells were visually classified for each period. Using this method, 225 ha of each aerial image was sampled. Land cover classification was based on the dominant land cover ( $\geq 50 \%$ of each cell) for the following classes: abandoned cropland, active cropland, woodland (forest/woodland/shrubland), grassland, and other (buildings/infrastructure/water/exposed rock/exposed soil). 'Abandoned cropland' was defined by land cover that contained visible, linear (i.e., human-made) boundaries but contained natural or semi-natural vegetation within these boundaries. There were cases of isolated trees within active cropland boundaries, but these were classified as 'active cropland' on evidence of recent ploughing or planted crop cover that could be distinguished from the surrounding landcover by texture and tone. With little to no information in the literature on the rate of encroachment of 'natural' vegetation into old fields, our conservative classification of 'woodland' or 'grassland' areas was when there were no discernible field boundaries around the vegetated areas. Considering the historical 
nature of the photographs, it was not possible to ground truth the classification results. Classification accuracy was not performed. Although the land cover classification was visual and subjective, it was consistently performed by one individual over the entire study.

\subsection{Local Perceptions on Crop Farming and Cropland Abandonment}

In July 2017, interviews were conducted in Transkei and KwaZulu, at two of the three sites in each former homeland where land cover change surveys had been performed (Figure 1). Prior to the site visits, thirty households were randomly selected using a superimposed grid in Google Earth (https://www.google.com/earth/). Households in the randomly selected grid cells were approached for an interview. If the household declined or no one was at home, the next household on the grid was selected. The oldest member of each household was interviewed using a combination of closed and open-ended questions in the local language, taking approximately 45 minutes per household to complete. Interviews were run to completion with no time limit, being sensitive to the respondents' need to elaborate through unstructured conversation. Respondents qualified for the interview by being either a past or active crop farmer. The questionnaire (see Supplementary Information), and this research, was broadly designed used a sustainable livelihoods approach [57]. The first section surveyed the respondents' involvement with croplands, active or past, as well as the reasons for ceasing farming. The second section explored the use of abandoned fields for livestock grazing or collection of natural resources and the third section on the farmers' perceptions of land use/cover change on active and abandoned cropland. Finally, household socio-economic characteristics and demographics were recorded. Interviews were conducted by one person (a postgraduate student who also performed the aerial image classification) with the aid of a translator, under the supervision of an experienced researcher well-versed in interview-based research. Questionnaire data were omitted from data analysis if they were not completed in full.

Respondents opinions were not prompted and thus respondents between and within regions gave different reasons for ceasing crop farming, or to potential enablers to restart farming. Response themes used in the analysis of the interview data to why the respondents stopped farming included: loss of cattle through mortality ("cattle death"), poor or declining soil fertility ("poor soils"), rainfall variability ("weather unpredictable"), non-farming-based cash supply ("alternate income"), lack of capital to purchase farming inputs ("too expensive"), no irrigation or regular access to water ("lack water"), inputs (costs and labor) exceed yield benefits ("not worth it"), lack of equipment or access to equipment ("lack equipment"), age or infirmity prevent labor ('not physically able"), a lack of interest from the youth in farming activities ("lazy youth"), and a lack of hired or family labor ("lack labor"). Response themes to respondents' requirements to restart crop farming include: access to financial credit systems ("credit system"), access to technological improvements in equipment and farming inputs ("cheaper farming methods"), regular access to irrigating water ("access to water"), financial and extension services support from government ("government support"), access to hired or government subsidized equipment such as tractors ("equipment availability"), training and education ("training/education on farming"), and interest from the (hired or family) youth in farming activities ("help from the youth").

\subsection{Data Analyses}

Spatial grid creation and manual land cover class classification was performed in ArcMap v10.3 [58]. Mean land cover classes were reported as percentages. Land cover change was reported as total percentage change and as annualized rates of change $\left(\%\right.$ year $\left.^{-1}\right)$ over 20 year and 60 year periods. Annualized rates of change $\left(\%\right.$ year $\left.^{-1}\right)$ are relative to the starting date and divided by the number of years between the time period. For example, if Venda woodland cover was $1.07 \%$ in 1950 and $4.67 \%$ in 1970 (Figure 2), the relative rate of change for woodland cover 1950-1970 was $0.17 \%$ year $^{-1}$ (Figure 3), a $336 \%$ increase. 
Interview data were not normal against Shapiro-Wilks normality tests, hence non-parametric Wilcoxon Rank Sum tests (test statistic: W) were used to test for differences between active farmer and past farmer household characteristics and livestock assets. Two-sample tests for equality of proportions with Yates continuity correction (test statistic: $\chi^{2}$ ) were used to test for differences in the ratio of male and female respondents between sites, and Pearson's $\chi^{2}$ tests (test statistic: $\chi^{2}$ ) within sites between active farmers, past farmers, and non-farmers. All respondent data analyses were performed in $\mathrm{R}$ v.3.4.1. [59] using base packages.

\section{Results}

\subsection{Land Cover Change in Former Homeland Communal Areas}

Land cover change analysis revealed an increase in the proportion of abandoned croplands with a concurrent decrease in the proportion of active croplands in all sites (Figure 2). Between the 1950s and 2010s, abandoned cropland cover increased by $0.13-0.28 \%$ in Transkei, Lebowa, and Venda sites and $0.08 \%$ in KwaZulu (Figure 3). The Transkei had the largest active cropland cover $(28.0 \%)$ in the 1950s, followed by Lebowa (25.3\%), KwaZulu (20.4\%) and, lastly, Venda (14.7\%) (Figure 2). The relative rate of cropland abandonment was highest in the Venda $\left(0.28 \%\right.$ year $\left.^{-1}\right)$ and Lebowa $\left(0.23 \%\right.$ year $\left.^{-1}\right)$ sites between the 1950s and 2010s (Figure 3), from a low starting cropland abandonment cover of $\leq 1 \%$ in the 1950s in both sites (Figure 2). Venda and Lebowa also lost the greatest proportion of their 1950s cover of active croplands faster than the other sites (Figure 2). By the 2010s, average abandoned cropland cover exceeded active cropland cover in three sites (KwaZulu, Lebowa, and Venda) and was about equal in the Transkei (Figure 2). Cropland abandonment rates between the 1970s and 1990s were particularly high, with relative annualized increases of $>0.1 \%$ in abandoned croplands $\left(0.23 \%\right.$ year $^{-1}$ in Lebowa).

Vegetation cover trends between the 1950s and 2010s overall showed an increase in woody vegetation and a decrease in grassland (Figure 2), but this was most pronounced in Venda which experienced $0.24 \%$ year $^{-1}$ relative increase in woody cover over 60 years. Thus, in Venda in the 1950s, only $1 \%$ of the land cover was wooded but this increased to $15 \%$ by the 2010 s (Figure 2).

Although grassland reduction rates were negligible to low ( $>-0.01 \%$ year $^{-1}$ in all sites), over 60 years this translated to a 30\% reduction in grass cover in Venda with an increase in woody cover of $15 \%$. In comparison, the Transkei lost $23 \%$ of grassland cover and gained $13 \%$ of woodland cover over the same period (Figure 2). In all sites, the rates of woodland increase were remarkably high between 1950 and 1970 and spanned a range from $\sim 0.01 \%$ year $^{-1}$ (KwaZulu and Transkei) to $0.06 \%$ year $^{-1}$ (Lebowa) and $0.17 \%$ year $^{-1}$ (Venda). 

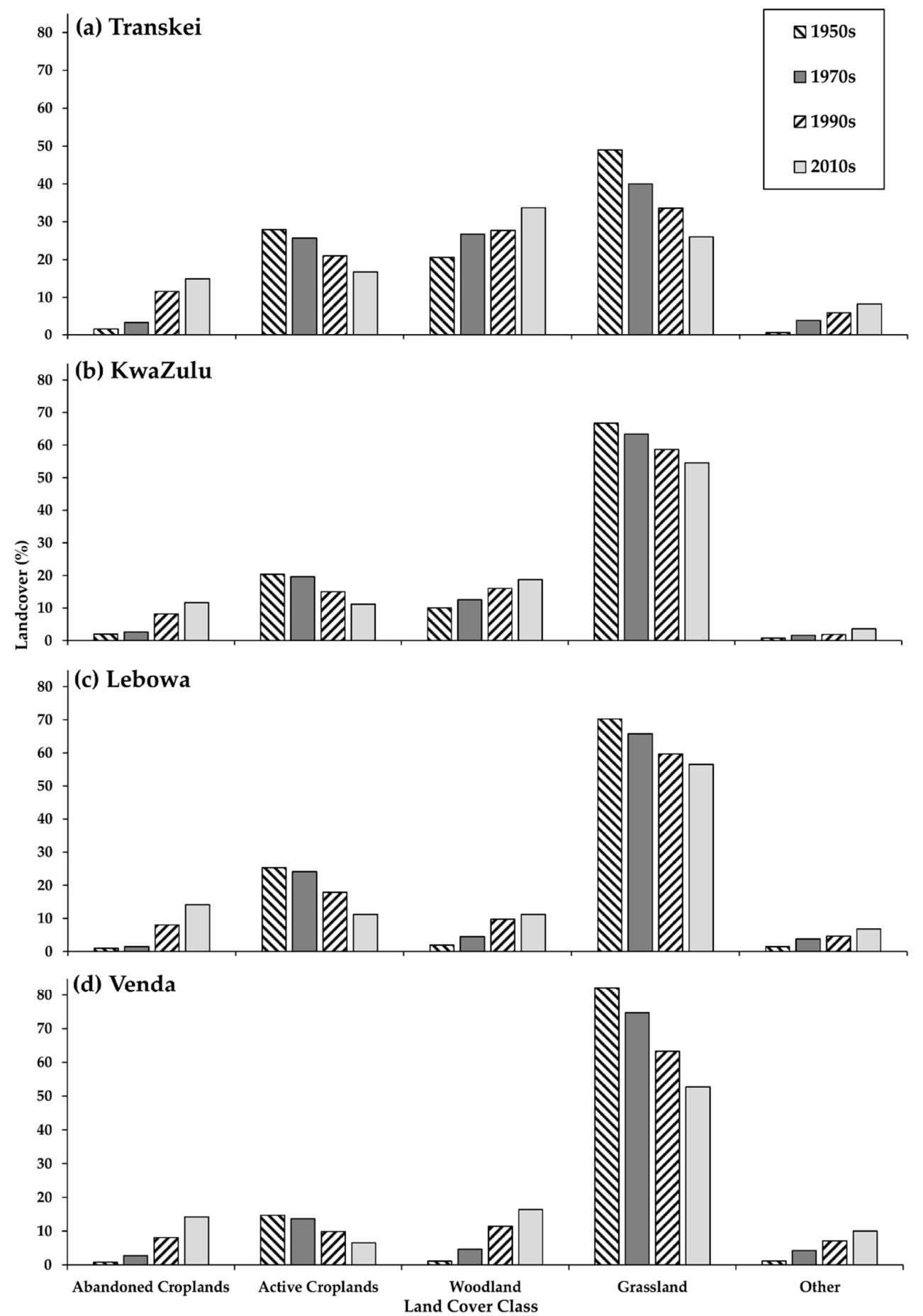

Figure 2. Average land cover (\%) in the (a) Transkei, (b) KwaZulu, (c) Lebowa, and (d) Venda sites. Land cover classes include: abandoned croplands, active croplands, woodlands (includes forests and shrublands), grasslands, and other (includes infrastructure, rock, and ground). 


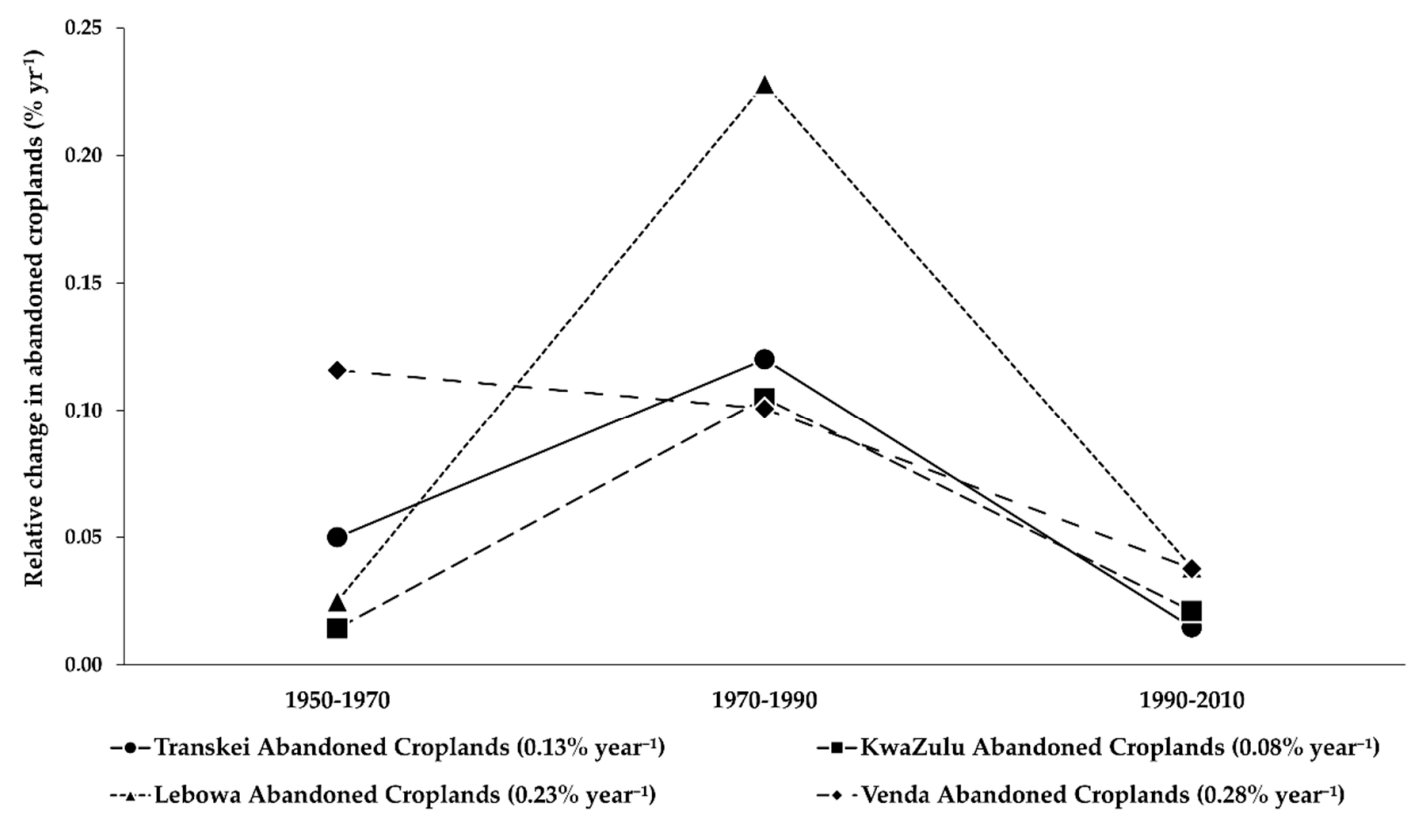

Figure 3. Change in abandoned cropland cover relative to the starting land cover in each period $\left(\%\right.$ year $\left.^{-1}\right)$. Annualised relative land cover rates from 1950-2010 are listed for each area in the legend.

\subsection{Active and Past Farmer Respondent Profiles and Perceptions on Agricultural Land-Use Changes}

The respondents interviewed in the Transkei and KwaZulu sites had similar demographic profiles, with approximately $30 \%$ male and $70 \%$ female respondents, about 45 years old with primary school education, and residing in average household sizes of four persons (Table 2). Low employment numbers were typical of both sites, although KwaZulu households had less cash-based income with $50 \%$ fewer wage earners and only one social grant (i.e., government welfare) per household (Table 2). The median number of social grants in the Transkei was three, with most KwaZulu households only receiving one grant. Despite mean household livestock numbers reflecting 2-4 sheep, cattle and goats per household, there was considerable variation within sites (compare mean and median livestock values in Table 2). A third of KwaZulu households owned no cattle and $12 \%$ owned $\geq 10$ cattle, whilst more than half of Transkei households owned no cattle and $13 \%$ owned $\geq 10$ cattle. Pigs were kept in only three Transkei households and were not kept at all in the KwaZulu sites. There were no differences between the age, education level, number of wage earners or social grants received per household between active farmers and past farmers (Table 2), although average household size was larger in actively farming households in the Transkei ( $\mathrm{W}=464.5, \mathrm{df}=58, p=0.012)$. However, the number of livestock owned was consistently higher in active farmer than past farmer households, in both the Transkei and KwaZulu sites (Table 2). Households with actively farmed land owned about seven-fold more cattle, goats and sheep, although there was substantial variation within active farmer households (Table 2). 
Table 2. Interview respondents' demographic and livelihood profiles (mean $\pm \mathrm{SD}$ ). Livestock numbers are reported as mean (median) $\pm \mathrm{SD}$ to demonstrate within group variation in ownership.

\begin{tabular}{|c|c|c|c|c|c|c|}
\hline & \multicolumn{3}{|c|}{ Transkei } & \multicolumn{3}{|c|}{ KwaZulu } \\
\hline & Combined & Active Farmers & Past Farmers & Combined & Active Farmers & Past Farmers \\
\hline \multirow[b]{2}{*}{ Gender "I } & Male $=17$ & Male $=6$ & Male $=11$ & Male $=16$ & Male $=5$ & Male $=11$ \\
\hline & Female $=43$ & Female $=8$ & Female $=35$ & Female $=44$ & Female $=13$ & Female $=31$ \\
\hline Age (years) & $49.4 \pm 13.3$ & $48.4 \pm 11.2$ & $49.7 \pm 14.0$ & $45.0 \pm 15.6$ & $43.1 \pm 13.8$ & $45.8 \pm 16.3$ \\
\hline No. of years of education ${ }^{+}$ & $6.0 \pm 4.5$ & $6.3 \pm 4.4$ & $5.8 \pm 4.6$ & $5.3 \pm 4.5$ & $5.7 \pm 4.7$ & $5.1 \pm 4.5$ \\
\hline Household size & $4.4 \pm 1.8$ & $5.5 \pm 2.1 *$ & $4.1 \pm 2.1$ & $4.1 \pm 2.0$ & $4.8 \pm 2.6$ & $3.7 \pm 1.7$ \\
\hline No. of wage earners per household & $0.4 \pm 0.5$ & $0.6 \pm 0.5$ & $0.4 \pm 0.5$ & $0.3 \pm 0.5$ & $0.3 \pm 0.5$ & $0.2 \pm 0.5$ \\
\hline No. of state welfare grants per household $\ddagger$ & $2.9 \pm 1.0 * / * * * \S$ & $2.5 \pm 1.0$ & $3.0 \pm 1.0$ & $1.4 \pm 1.5$ & $1.7 \pm 1.5$ & $1.3 \pm 1.5$ \\
\hline No. of cattle per household & $2.8(0.0) \pm 4.6$ & $8.1(10.0) \pm 6.9^{* * *}$ & $1.1(0.0) \pm 1.6$ & $2.9(1.0) \pm 4.5$ & $7.2(4.0) \pm 6.3^{* * *}$ & $1.1(1.0) \pm 1.3$ \\
\hline No. of goats per household & $3.5(3.5) \pm 5.0$ & $10.4(10.5) \pm 6.3 * * *$ & $1.4(1.0) \pm 1.5$ & $3.5(1.0) \pm 6.4$ & $9.7(10.0) \pm 8.9^{* * *}$ & $0.8(0.0) \pm 1.2$ \\
\hline No. of sheep per household & $3.2(1.0) \pm 4.3$ & $9.6(10.0) \pm 3.8^{* * *}$ & $1.2(0.5) \pm 1.9$ & $3.2(1.0) \pm 6.2$ & $8.1(0.0) \pm 9.6$ & $1.1(1.0) \pm 1.1$ \\
\hline
\end{tabular}

Differences between gender proportions within sites were tested using two-sample tests for equality of proportion with Yates continuity corrections. All other categories in the table were tested with Wilcoxon Rank Sum tests both within and between sites. ${ }^{\dagger} 1-7$ years = Primary school education, 8-12 years = Secondary School Education. ${ }^{\ddagger}$ State grants include: child support, disability and pension grants. * Denotes statistically significant differences at $p<0.05$ in Wilcoxon Rank Sum Tests. If * occurs in the combined column, significant differences were present between active farmers and past farmers between sites. If * occurs in the active/past farmer column, significant differences were present between active and past farmers within the sites. ${ }^{* *}$ Denotes significant differences at $p<0.01$. ${ }^{* * *}$ Denotes significant differences at $p<0.001$. ${ }^{\S}$ Significant differences between Transkei and KwaZulu active farmers was at $p<0.05$, differences between Transkei and KwaZulu past farmers was at $p<0.001$. 
There were similar numbers of respondents actively farming in both sites $(23 \%$ in Transkei and $32 \%$ in KwaZulu), with $<10 \%$ of people in both sites having never farmed. There was no significant association between active farming, past farming, or never farmed households between the Transkei and KwaZulu sites $\left(\chi^{2}=3.57, \mathrm{df}=2, p=0.168\right)$. On average, past farmers in KwaZulu had exited farming $24.7 \pm 4.6$ years ago compared to $22.5 \pm 6.7$ years ago in the Transkei sites.

There was no significant difference between when active and past farmers established their croplands in the Transkei ( $\mathrm{W}=299.50, \mathrm{df}=54, p=0.924: 27.3 \pm 8.8$ years ago), but active farmers in KwaZulu had cleared their croplands significantly later (20.0 \pm 8.0 years ago) than past farmers $(30.3 \pm 6.1$ years ago $)(\mathrm{W}=533.00, \mathrm{df}=52, p<0.001)$. Both past and active farmers in all the sites predominantly planted maize, but also grew pumpkins, cabbages, beans, potatoes and peas. All Transkei respondents agreed that the farming contribution to livelihoods was high to very high, regardless of whether they were actively farming crops or not. KwaZulu respondents had a similar view, although $10 \%$ felt that the farming contribution to their livelihoods was intermediate. Past farmers in both KwaZulu (45\% respondents) and Transkei (33\% respondents) agreed that livestock grazing occurred on abandoned croplands, particularly in the dry season, although active farmers disagreed (95\% respondents) that grazing occurred on old croplands. There was an almost unanimous affirmative response to the abandoned croplands being used for non-timber forest product collection (e.g., fuelwood harvesting), but many required land owners' permission before these activities could occur on the abandoned croplands. The response to whether land cover had changed in the last 70 years was almost undisputed (90\% in KwaZulu, 100\% in Transkei) that woody vegetation densities had increased in the abandoned croplands, with respondents saying:

"The grasses have turned into forests now"

and

"There are many trees ... where people used to plant"

A few respondents expressed safety concerns with regards to bush encroachment:

"We can no longer walk through the fields because there's (sic) too many trees and it's dangerous."

\subsection{Perceptions on the Reasons for the Decline in Crop Farming}

All respondents felt that agriculture did not play as great a role as it did historically, when they were young. The reasons given by respondents for exiting crop farming (Figure 4) and their requirements for restarting crop farming (Figure 5) were not determined a priori, but were emergent themes provided by the respondents. Thus, not all categories are mentioned in all areas. For example, poor soil is not given as a reason for exiting farming by any Transkei respondents, but was a common response from KwaZulu past farmers (Figure 4). A common response to the perceived reasons for the overall trend of decline in crop farming was the recent droughts (KwaZulu: 92\% respondents, Transkei: $29 \%$ ). KwaZulu respondents also attributed agricultural decline to rainfall variability (55\% of respondents), the high cost of fertilizer and seed ( $29 \%$ of respondents) and a lack of assistant labor (17\% of respondents). Many Transkei respondents blamed a lack of access to water (67\% of respondents) to the decline in crop farming. Both areas attributed agricultural decline to a lack of interest in farming amongst the youth $(>24 \%)$ which was frequently conveyed with the phrase: "lazy youth". Rainfall variability and lack of access to water were themes that emerged when past farmers recounted reasons for exiting crop farming, but the main reported proximal factor was the death of their cattle (Figure 4). The effort required for ploughing was a common theme in both KwaZulu and Transkei, emerging through a lack of cattle for ploughing, a lack of willing youth and other labor assistance, the expense and unavailability of ploughing equipment, and ageing respondents no longer able to physically manage the fields themselves (Figure 4). Transkei past farmers attributed poor soil quality to their inability to farm and $36 \%$ of these past farmers had an alternate source of income. Many respondents 
said that farming was "not worth" the expense of equipment, seed and fertilizer, and well as the physical labor required (Figure 4).

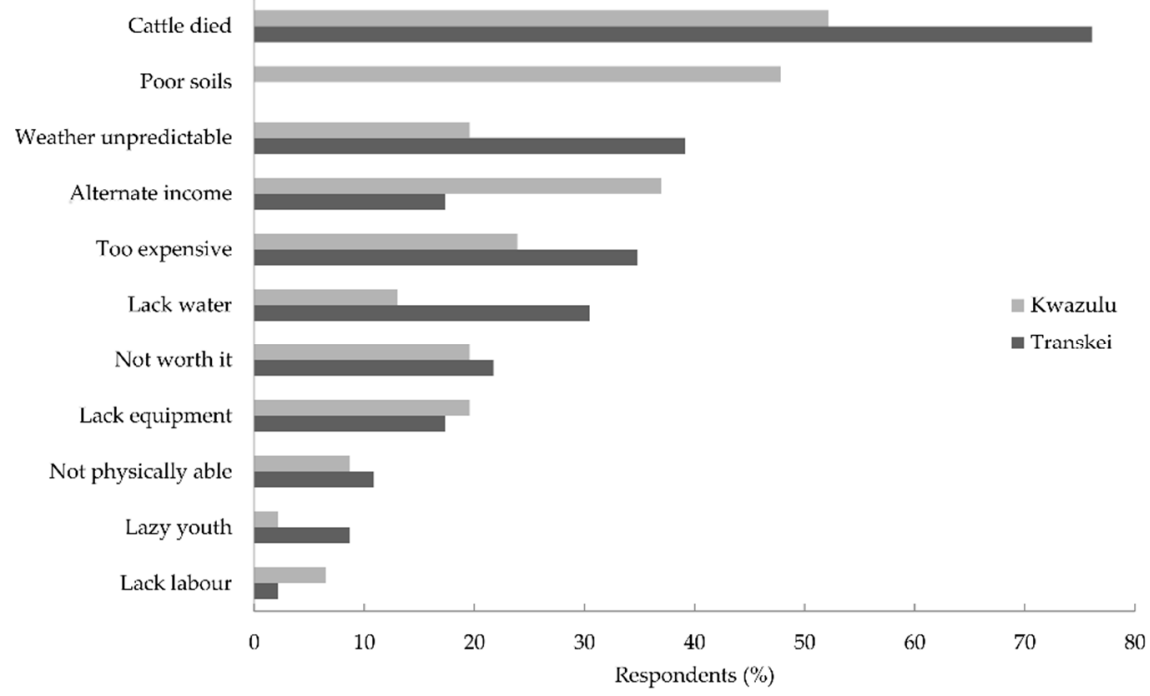

Figure 4. Reasons given by past farmers for exiting their own crop farming activities in KwaZulu $(n=42)$ and Transkei $(n=48)$. Cumulative respondent percentages total more than $100 \%$ as more than one answer could be provided.

More than $80 \%$ of respondents affirmed that they would like to restart crop farming, although $44 \%$ of KwaZulu respondents conceded that it was unlikely to occur as they were too old, or it was too expensive. Many respondents felt that farming was a traditional activity (Transkei: $66 \%$ respondents, KwaZulu: $38 \%$ respondents), that they identified as 'farmers' even if they were not actively farming (Transkei: $7 \%$ respondents. KwaZulu: $12 \%$ respondents) and that farming contributed to their livelihoods, through income generation (Transkei: 25\% respondents, KwaZulu: 10\% respondents). When they were asked what would enable them to restart crop farming, KwaZulu respondents requested access to credit systems, cheaper farming methods and farming equipment (Figure 5). Transkei respondents requested access to water, cheaper farming methods and government support (Figure 5).

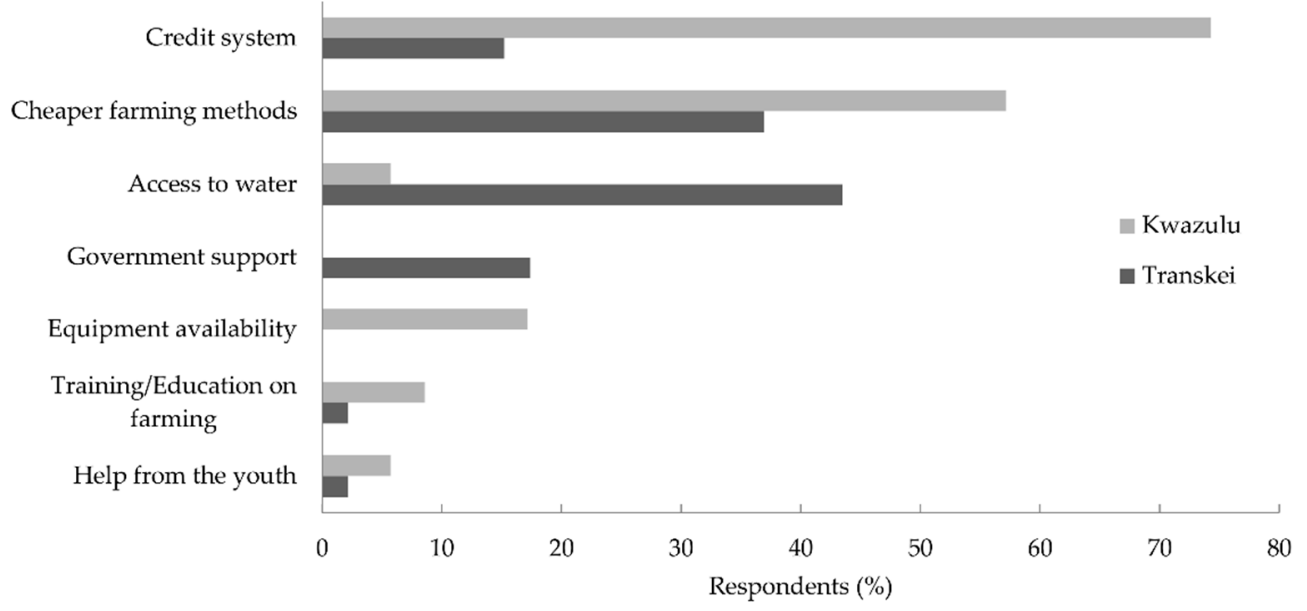

Figure 5. Past farmer requirements to restart crop farming in KwaZulu $(n=42)$ and Transkei $(n=48)$. Cumulative respondent percentages total more than $100 \%$ as more than one answer could be provided. 


\section{Discussion}

The long-term analysis of land cover change in the former South African homeland sites revealed a widespread increase in cropland abandonment between the 1950s and 2010s with cropland abandonment rates peaking in all surveyed homelands between 1970 and 1990. The annualized relative cropland abandonment rates between 1970 and 1990 exceeded $0.10 \%$, with extremely high rates in Lebowa and Venda. This trend in cropland abandonment coincided with the peak of South Africa's Betterment Planning in the 1970s and 1980s [41,48]. Betterment Planning, initiated in 1936, discontinued farming on land deemed unsuitable for agriculture and demarcated new arable areas. The aim of Betterment Planning was ecological and agricultural sustainability, as well as facilitating service and infrastructure provision by collectivizing dwellings into nuclear villages [60]. However, in many areas the net result of Betterment Planning was a reduction in zoned arable land [60]. The newly demarcated fields were situated further away from homesteads than previous fields [48]. As an unintended consequence, Betterment Planning disincentivized agricultural investment as the new fields needed substantial initial labor and financial investment to clear [60], and increased time and effort to manage across larger home-field distances [48]. Much of KwaZulu did not experience Betterment Planning and, perhaps consequently, this study's surveyed KwaZulu sites had the lowest proportion of abandoned croplands. Despite the post-Apartheid South African government's attempts to reverse inequitable land distribution amongst black and white South Africans with the White Paper on South African Land Policy (1997) which mapped out restitution, redistribution and land tenure policies [47], cropland abandonment rates from the 1990s to 2010s still exceeded cropland abandonment rates before the 1970s in KwaZulu and Lebowa. Previous studies on cropland abandonment in former homelands have mostly shown declines in agricultural activity, with the exception of villages in the former Gazankulu with either stable agricultural engagement or a slight increase [61]. However, these rates are extremely variable within homelands, dependent on localized patterns as well as start date of cropland abandonment survey. Whilst we recorded rates of $0.12 \%$ year $^{-1}$ (1970s-1990s) and $0.01 \%$ year $^{-1}$ (1990s-2010s) in the Transkei sites, another Transkei village (Willowvale) had cropland abandonment rates of $0.1 \%$ year $^{-1}$ (1961-2009) [16]. Similarly, this study's surveyed Venda sites had an increase of $0.04 \%$ year $^{-1}$ (1990s-2010s) of abandoned croplands whilst Lidzhegu and Palamuleni [62] recorded a change of $0.8 \%$ year $^{-1}$ over a similar period (1994-2007) in a different Venda village (Makotopong). The Lebowa rates of active cropland cover change $\left(-0.02 \%\right.$ year $^{-1}$ : 1990s-2010s) in this study were vastly different to McCusker's [47] study adjacent to Lebowa over five sites which recorded $-1.2 \%$ year $^{-1}$ (1989-2000). Yet the southern African region, as a whole, has had an increase in total farmland area $[14,53]$. The variation in land abandonment is part local-scale context and part large-scale homogenization of smallholder, government and corporate farm lands, obscuring the extent of localized deagrarianization. Studies that do not differentiate between different farming types could conflate expanding crop farming operations on commercial farms with cropland abandonment by smallholder, subsistence farmers. Considering the importance of smallholder farming to food production and rural livelihoods, large-scale, but fine resolution assessments of cropland abandonment are required to understand the extent of cropland farming decline (see an excellent example of disaggregated global farming data for smallholder farmers: [3]).

The responses of past farmers to when they last farmed in KwaZulu and Transkei support the surveyed results of a peak in cropland abandonment between the 1970s and 1990s. Most farmers indicated they stopped planting crops in their croplands from the late 1980s to the late 1990s (mean period in KwaZulu = 1992; Transkei $=1994$ ), at the dawn of democracy. Up to $80 \%$ of farmers attributed the death of their cattle (i.e., loss of draught power for ploughing) as the reason for ceasing crop farming. Livestock owners in the Transkei reported loss of cattle to drought and disease or livestock being sold and not replaced [16]. Increased cattle mortality in former homelands has also been attributed to the withdrawal of state-provided agricultural extension services and veterinary assistance (including dipping programs) for livestock as the post-1994 democratic government diverted resources to urban development [41]. Although household cattle ownership in former homelands has 
remained stable, or increased in some cases, the proportion of households owning cattle has decreased substantially [63]. Challenges to livestock ownership include: government development projects that are at odds with livestock husbandry, disease, a reduction in the number of herd boys with increases in school attendance, declining use of cattle as a 'savings option' in favor of cash-based alternatives, and livestock theft [63]. In our study, livestock ownership in KwaZulu and Transkei emerged as a distinguishing characteristic between active and past farmers with active farmers owning up to seven-fold more cattle, goats and sheep.

Other commonly cited reasons for the cessation of crop farming in KwaZulu and Transkei were similarly related to loss of cropland ploughing ability: ageing farmers were no longer physically able to plough, a lack of access to ploughing equipment, insufficient supplementary income to purchase or hire tractors, and a younger, modernized youth less interested in farming. The 'youth question' is an important aspect of deagrarianization as growing numbers of rural youth refuse to provide labor for family farms, whilst those young people who are inclined to farm are frustrated at the lack of arable land as land ownership is held by the older generations [64]. The youths' aspiration for a better life than the marginal means of living as a rural, smallholder farmer have driven a migration away (or attempts to escape) from an agrarian lifestyle [65]. The youths' disengagement with smallholder crop farming is supported by a recent Labor Force Survey which found low participation rates in 15-24 year old people in farming, which, when combined with an absence of male labor and the 'time poverty' of female laborers who carry multiple household and domestic chores [21], results in severe labor constraints for farming families. Compounding the labor problem, changes to the rural labor market have reduced the involvement of migrant labor in farming. Previously migrant labor would return after a short-term contract with their remittances to purchase seeds and assist with ploughing. But now full-time, often urban-employed labor only return in summer to celebrate important religious and cultural events at their rural home [9]. 'Undercultivation' in former homelands was also attributed to a lack of capital for seeds and fertilizer and fencing to protect crops from livestock [48]. Curiously, many Transkei farmers mentioned soil fertility issues for the decline in crop farming, but this was not mentioned by any KwaZulu farmers. The authors do not know why it was such a prevalent concern for the Transkei respondents, and this requires further investigation.

The KwaZulu and Transkei active farmers and past farmers' perceptions on the reasons for disengagement with agriculture also included access to alternative incomes and all the households in this research received at least one social grant. Rural South African households are increasingly dependent on commercially produced food and non-agriculturally derived incomes, including stateand urban-derived cash incomes [46,65]. The expansion of supermarkets into rural areas [21,64], as well as the dominance of cash-based societies and rural outmigration for employment opportunities [23], disincentivizes subsistence agriculture and changes rural agrarian identities [9]. Urban migration in a developing world context has created "remittance landscapes"-land use change driven by wages earned in urban centers and remitted to rural communal lands, altering the distribution of cropland and others land uses [19]. These local factors are also affected by globalization, rural-urban migration and strengthening rural-urban connections $[9,66]$. In contrast, in the rest of the southern African region where state-derived incomes are nonsignificant, smallholder farming remains crucial to rural households [67]. Some of the factors associated with European farmland abandonment are similar to the South African scenario (e.g., ageing farmer population, small farms that provide low farm income) whilst other factors are vastly different (e.g., the expansion of urban areas into farmland, farmland conversion to leisure tourism areas) [17]. Thus, generalizations are challenging as factors of cropland abandonment drivers are the emergent properties of site-specific local-global, rural-urban connections.

Compounding socio-economic drivers are extreme climatic events which are predicted to increase in the future [68]. Both Transkei and KwaZulu past farmers blamed water security, both variable rainfall and the lack of access to irrigated water, for agricultural abandonment. During the peak cropland abandonment period in this survey (1970s-1990s), several extreme climatic events occurred. Devastating floods in 1981, were followed by severe drought in 1983 with some regions receiving < $15 \%$ 
of average summer rainfall [39]. Severe drought, below the 25th percentile of the climatological record, occurred during the El-Niño seasons in the early 1980s and again in the early 1990s [69]. Droughts, occurring particularly in early-to-mid summer and over normally low rainfall regions, drastically reduces crop yields [69]. In addition, Transkei respondents overwhelmingly (relative to KwaZulu respondents) attributed crop farming declines to a lack of access to water. This difference could be accounted for by the later summer rainfall in the Transkei compared to midsummer rainfall in KwaZulu, although they receive similar mean annual precipitation [70]. These sequential climatic disasters erode the resilience of subsistence farmers, depleting their food and financial stores, creating a positive feedback loop of decreasing agricultural activity. Alternately, disengagement with subsistence agriculture may free up the associated time, labor and input costs of crop farming, creating alternative income-earning opportunities for rural households. However, these implications for non-farming households are currently unknown, but are likely to be capital-dependent (human, financial, physical, natural and social) at the household level.

Overwhelmingly, respondents agreed that abandoned croplands became bush encroached which supported our aerial survey findings (up to $0.16 \%$ year $^{-1}$ ) increase in woodland cover at the expense of grass cover. The Venda sites had both the highest rates of both cropland abandonment and woody encroachment. Historical photographic records of Venda show the transformation of grasslands into impenetrable shrublands (1935-1972), dominated by stands of native Senegalia ataxacantha and alien invasive plants [71]. A recent national survey (1990-2013) by Skowno et al. [72] documented nationwide increases in woodlands, but the highest rates were in traditional communal rangelands $\left(0.46 \%\right.$ year $\left.^{-1}\right)$. Recent work on bush encroachment shows a combination of local (e.g., heavy grazing, fire management) and global (e.g., $\mathrm{CO}_{2}$ fertilization) causes [73,74], where woody encroachment on abandoned croplands is an emergent land cover result of the interaction between climate change and land management (e.g., [69,74]). Bush encroachment will likely have implications for ecosystem service delivery [75]. For example, increased woody plant abundance may be beneficial for fuelwood harvesting or goat farming, but may decrease grazing for cattle. Abandoned croplands may be perceived as a loss of traditional landscapes [27], or undesirable. Respondents also expressed safety concerns about the densely wooded abandoned croplands. South Africa's high violent crime rate has created a culture of fear and local residents were concerned that the densely wooded former croplands provided cover for potential attackers on lone residents. Bush encroachment in abandoned croplands may bring pests (e.g., monkeys, wild pigs) and dangerous animals (e.g., snakes) closer to homes [16]. The change in ecosystem services (or disservices) and ecological functioning as a result of vegetation succession on abandoned croplands is, mostly, unknown. To date, international studies have shown limited regeneration of abandoned farmland to a 'historical undisturbed' state (see reviews: $[13,18,27]$ ).

This study's findings contribute to understanding of the long-term, local rates of cropland abandonment, the importance of livestock ownership to rural, subsistence farmers, and the farmers' perceptions of factors in the decline in smallholder crop farming. However, we caution that these findings are not easily generalizable owing to the fine-scale nature of cropland abandonment, as well as the high variation both within and between former homelands. Large spatial and temporal variation would usually be explored using satellite remote sensing products, but due to the small size of the croplands and the difficulty in classifying 'active' and 'abandoned' croplands, these methods, in the absence of extensive fieldwork validation and classification refinement (i.e., considerable associated financial and time costs of extensive ground truthing) will contain considerable inaccuracies.

\section{Conclusions}

The pervasive local trend of cropland abandonment is likely to increase as national interventions in South Africa to reverse the trend of agricultural disengagement have been largely unsuccessful $[5,76]$. If policy-makers aim to increase rural subsistence farming, the respondent requirements for water security needs to be addressed, as well as access to credit for farmers to purchase seed and fertilizers. However, government and development finance support should go beyond primary production, 
and support smallholder and emerging farmers across the agricultural value chain, including storage, transport, logistics and marketing. Perhaps an additional focus of support should be on subsistence farming to increase food security through home gardens which are smaller and more manageable for older rural farmers [46]. In some areas the decline in subsistence crop farming has been matched by an increase in home gardens $[43,46,48]$, but supporting different crops types, and a change in labor relations. Rainwater collection tanks could be incorporated into home garden design to buffer against rainfall variability and drought. Share-cropping and land lease arrangements for unused croplands could be encouraged for interested landless farmers, although historically leasing and sharecropping levels are low, and, when present, fraught with conflict [77]. Regardless of the success of smallholder agricultural incentives, there will still be large areas of abandoned croplands and the ecological and ecosystem service trade-offs of these old fields is largely unknown. For example, although bush encroachment may decrease albedo and sequester carbon, there are also negative ecosystem service and ecosystem functioning consequences (see reviews: $[13,18]$ ) as well as social repercussions. However, cropland abandonment and the subsequent vegetation succession are not end states [18] and the multiple possible trajectories of abandoned croplands is a topic that needs further investigation and local scale models, especially to explore where intervention may best be applied to achieve desirable outcomes.

Supplementary Materials: The following are available online at http://www.mdpi.com/2073-445X/7/4/121/s1.

Author Contributions: Conceptualization, C.M.S.; Data curation, P.J.M.; Formal analysis, D.B. and P.J.M.; Funding acquisition, C.M.S.; Investigation, D.B., C.M.S. and P.J.M.; Methodology, D.B., C.M.S. and P.J.M.; Project administration, C.M.S. and P.J.M.; Resources, C.M.S.; Supervision, C.M.S. and P.J.M.; Visualization, P.J.M.; Writing —original draft, D.B. and P.J.M.; Writing—review \& editing, C.M.S. and P.J.M.

Funding: Funding for this work was provided by the DST/NRF Chair in “Interdisciplinary Science in Land and Natural Resource Use for Sustainable Livelihoods". Any opinion, finding, conclusion or recommendation expressed in this material is that of the authors and the NRF does not accept any liability in this regard.

Acknowledgments: We thank Sakhiwo Habana for translation assistance in the field. This study was approved by the Rhodes University Ethics committee. Permission to work in each area was granted by the local Traditional Authority. Written consent was sought and in cases where the interviewee was illiterate, verbal consent was sought and noted.

Conflicts of Interest: The authors declare no conflict of interest.

\section{References}

1. World Resources Institute (WRI). World Resources Report 2013-2014: Creating a Sustainable Food Future; World Resources Institute: Washington, DC, USA, 2014.

2. Alliance for a Green Revolution in Africa (AGRA). Africa Agricultural Status Report: Climate Change and Smallholder Agriculture in Sub-Saharan Africa; Alliance for a Green Revolution in Africa: Nairobi, Kenya, 2014.

3. Samberg, L.H.; Gerber, J.S.; Ramankutty, N.; Herrero, M.; West, P.C. Subnational distribution of average farm size and smallholder contributions to global food production. Environ. Res. Lett. 2016, 11, 1-11. [CrossRef]

4. Wiggins, S. Smallholder farming in Africa: Stasis and dynamics. In Renewing Development in Sub-Saharan Africa: Policy, Performance and Prospects; Belshaw, D., Livingstone, I., Eds.; Routledge: London, UK, 2002; pp. 101-120. ISBN 2001019955.

5. Pienaar, L.; Von Fintel, D. Hunger in the former apartheid homelands: Determinants of convergence one century after the 1913 Land Act. Agrekon 2014, 53, 38-67. [CrossRef]

6. Von Grebmer, K.; Headey, D.; Olofinbiyi, T.; Wiesmann, D.; Fritschel, H.; Yin, S.; Yohannes, Y. Global Hunger Index 201: The challenge of Hunger: Building Resilience to Achieve Food and Nutrition Security; IFPRI/Welthungerhilfe/Concern Worldwide/IDS: Washington, DC, USA, 2013.

7. Schmidhuber, J.; Shetty, P. The nutrition transition to 2030. Why developing countries are likely to bear the major burden. Acta Agric. Scand. Sect. C Food Econ. 2005, 2, 150-166. [CrossRef]

8. Shackleton, C.M.; Shackleton, S.E.; Cousins, B. The role of land-based strategies in rural livelihoods: The contribution of arable production, animal husbandry and natural resource harvesting in communal areas in South Africa. Dev. South. Afr. 2001, 18, 581-604. [CrossRef] 
9. Hebinck, P.; Mtati, N.; Shackleton, C. More than just fields: Reframing deagrarianisation in landscapes and livelihoods. J. Rural Stud. 2018. [CrossRef]

10. Deininger, K.; Byerlee, D. Rising Global Interest in Farmland: Can It Yield Sustainable and Equitable Benefits? The World Bank: Washington, DC, USA, 2011.

11. United Nations Conference on Trade and Development (UNCTAD). Commodities and Development Report 2015: Smallholder Farmers and Sustainable Commodity Development; United Nations Conference on Trade and Development: Geneva, Switzerland, 2015.

12. Ramankutty, N.; Foley, J.A. Estimating historical changes in global land cover: Croplands from 1700 to 1992. Glob. Biogeochem. Cycles 1999, 13, 997-1027. [CrossRef]

13. Cramer, V.A.; Hobbs, R.J.; Standish, R.J. What's new about old fields? Land abandonment and ecosystem assembly. Trends Ecol. Evol. 2008, 23, 104-112. [CrossRef] [PubMed]

14. Li, S.; Li, X. Global understanding of farmland abandonment: A review and prospects. J. Geogr. Sci. 2017, 27, 1123-1150. [CrossRef]

15. Bryceson, D.F. Deagrarianization and rural employment in sub-Saharan Africa. World Dev. 1996, $24,97-111$. [CrossRef]

16. Shackleton, R.; Shackleton, C.; Shackleton, S.; Gambiza, J. Deagrarianisation and forest revegetation in a biodiversity hotspot on the Wild Coast, South Africa. PLoS ONE 2013, 8, e100463. [CrossRef] [PubMed]

17. Pointereau, P.; Coulon, F.; Girard, P.; Lambotte, M.; Stuczynski, T.; Sánchez Ortega, V.; Del Rio, A. Analysis of Farmland Abandonment and the Extent and Location of Agricultural Areas that Are Actually Abandoned or Are in Risk to Be Abandoned; European Commission, Joint Research Centre, Institute for Environment and Sustainability: Ispra, Italy, 2008.

18. Munroe, D.K.; van Berkel, D.B.; Verburg, P.H.; Olson, J.L. Alternative trajectories of land abandonment: Causes, consequences and research challenges. Curr. Opin. Environ. Sustain. 2013, 5, 471-476. [CrossRef]

19. Lambin, E.F.; Turner, B.L.; Geist, H.J.; Agbola, S.B.; Angelsen, A.; Bruce, J.W.; Coomes, O.T.; Dirzo, R.; Fischer, G.; Folke, C.; et al. The causes of land-use and land-cover change: Moving beyond the myths. Glob. Environ. Chang. 2001, 11, 261-269. [CrossRef]

20. Bryceson, D.F.; van der Laan, C. De-Agrarianization in Africa; Afrika-Studiecentrum Leiden: Leiden, The Netherlands, 1994.

21. Palmer, K.; Sender, J. Prospects for on-farm self-employment and poverty reduction: An analysis of the South African income and expenditure survey 2000. J. Contemp. Afr. Stud. 2006, 24, 347-376. [CrossRef]

22. Daugstad, K.; Rønningen, K.; Skar, B. Agriculture as an upholder of cultural heritage? Conceptualizations and value judgements-A Norwegian perspective in international context. J. Rural Stud. 2006, 22, 67-81. [CrossRef]

23. Ncube, N.; Tanga, P.T.; Bhumira, B. The impact of de-agrarianisation on the socio-economic well-being of rural inhabitants in South Africa. J. Hum. Ecol. 2014, 48, 399-406. [CrossRef]

24. Queiroz, C.; Beilin, R.; Folke, C.; Lindborg, R. Farmland abandonment: Threat or opportunity for biodiversity conservation? A global review. Front. Ecol. Environ. 2014, 12, 288-296. [CrossRef]

25. Rey Benayas, J.; Martins, A.; Nicolau, J.M.; Schulz, J.J. Abandonment of agricultural land: An overview of drivers and consequences. CAB Rev. Perspect. Agric. Vet. Sci. Nutr. Nat. Resour. 2007, 2. [CrossRef]

26. Cerqueira, Y.; Navarro, L.; Maes, J.; Marta-Pedroso, C.; Pradinho Honrado, J.; Perreira, H. Ecosystem services: The opportunities of rewilding in Europe. In Rewilding European Landscapes; Pereira, H.M., Navarro, L.M., Eds.; Springer: Heidelberg, Germany, 2015; pp. 47-64.

27. Navarro, L.M.; Pereira, H.M. Rewilding abandoned landscapes in Europe. In Rewilding European Landscapes; Pereira, H.M., Navarro, L.M., Eds.; Springer: Heidelberg, Germany, 2015; pp. 3-24.

28. Verburg, P.H.; Overmars, K.P. Combining top-down and bottom-up dynamics in land use modeling: Exploring the future of abandoned farmlands in Europe with the Dyna-CLUE model. Landsc. Ecol. 2009, 24, 1167-1181. [CrossRef]

29. Pereira, H.M.; Navarro, L.M. Rewilding European Landscapes; Springer: Heidelberg, Germany, 2015; ISBN 9783319120393.

30. Laue, J.E.; Arima, E.Y. Spatially explicit models of land abandonment in the Amazon. J. Land Use Sci. 2016, 11, 48-75. [CrossRef] 
31. Cava, M.G.B.; Pilon, N.A.L.; Ribeiro, M.C.; Durigan, G. Abandoned pastures cannot spontaneously recover the attributes of old-growth savannas. J. Appl. Ecol. 2017, 12, 3218-3221. [CrossRef]

32. Lambin, E.F.; Meyfroidt, P. Land use transitions: Socio-ecological feedback versus socio-economic change. Land Use Policy 2010, 27, 108-118. [CrossRef]

33. MacDonald, D.; Crabtree, J.R.; Wiesinger, G.; Dax, T.; Stamou, N.; Fleury, P.; Gutierrez Lazpita, J.; Gibon, A. Agricultural abandonment in mountain areas of Europe: Environmental consequences and policy response. J. Environ. Manag. 2000, 59, 47-69. [CrossRef]

34. Vinogradovs, I.; Nikodemus, O.; Elferts, D.; Brūmelis, G. Assessment of site-specific drivers of farmland abandonment in mosaic-type landscapes: A case study in Vidzeme, Latvia. Agric. Ecosyst. Environ. 2018, 253, 113-121. [CrossRef]

35. Hatna, E.; Bakker, M.M. Abandonment and expansion of arable land in Europe. Ecosystems 2011, 14, 720-731. [CrossRef]

36. Hinojosa, L.; Napoléone, C.; Moulery, M.; Lambin, E.F. The "mountain effect" in the abandonment of grasslands: Insights from the French Southern Alps. Agric. Ecosyst. Environ. 2016, 221, 115-124. [CrossRef]

37. Seto, K.C.; Reenberg, A.; Boone, C.G.; Fragkias, M.; Haase, D.; Langanke, T.; Marcotullio, P.; Munroe, D.K.; Olah, B.; Simon, D. Urban land teleconnections and sustainability. Proc. Natl. Acad. Sci. USA 2012, 109, 7687-7692. [CrossRef] [PubMed]

38. Keenleyside, C.; Tucker, G. Farmland Abandonment in the EU: An Assessment of Trends and Prospects; WWF and IEEP: London, UK, 2010. Available online: https:/ /ieep.eu/uploads/articles/attachments /60c46694-1aa7454e-828a-c41ead9452ef/Farmland_abandonment_in_the_EU_-_assessment_of_trends_and_prospects_-_ FINAL_15-11-2010_.pdf?v=63664509740 (accessed on 20 September 2018).

39. Kirsten, J.F.; Van Zyl, J.; Van Rooyen, J. South African agriculture during the 1980s. S. Afr. J. Econ. Hist. 1994, 9, 19-48. [CrossRef]

40. Ngidi, M. Exploring the Population and Economic Growth Dynamics in Former Homeland Settlements between 1996 and 2011. Master's Thesis, Stellenbosch University, Stellenbosch, South Africa, 2014.

41. Hebinck, P.; van Averbeke, W. Rural transformation in the Eastern Cape. In Livelihoods and Landscapes: The People of Guquka and Koloni and Their Resources; Hebinck, P., Lent, P.C., Eds.; Brill: Leiden, The Netherlands, 2007; pp. 33-66. ISBN 9789004161696.

42. Andrew, M.; Ainslie, A.; Shackleton, C. Land Use and Livelihoods; PLAAS, University of the Western Cape: Cape Town, South Africa, 2003.

43. Shackleton, S.; Luckert, M. Changing livelihoods and landscapes in the rural Eastern Cape, South Africa: Past influences and future trajectories. Land 2015, 4, 1060-1089. [CrossRef]

44. Twyman, C.; Sporton, D.; Thomas, D.S.G. "Where is the life in farming?": The viability of smallholder farming on the margins of the Kalahari, Southern Africa. Geoforum 2004, 35, 69-85. [CrossRef]

45. Hajdu, F. Relying on jobs instead of the environment? Patterns of local securities in rural Eastern Cape, South Africa. Soc. Dyn. 2005, 31, 235-260. [CrossRef]

46. Masunungure, C.; Shackleton, S. Exploring long-term livelihood and landscape change in two semi-arid sites in southern Africa: Drivers and consequences for social-ecological vulnerability. Land 2018, 7, 50. [CrossRef]

47. McCusker, B. Land use change on recently redistributed farms in the Northern Province, South Africa. Hum. Ecol. 2004, 32, 49-75. [CrossRef]

48. Andrew, M.; Fox, R.C. “Undercultivation” and intensification in the Transkei: A case study of historical changes in the use of arable land in Nompa, Shixini. Dev. South. Afr. 2004, 21, 687-706. [CrossRef]

49. Giannecchini, M.; Twine, W.; Vogel, C. Land-cover change and human-environment interactions in a rural cultural landscape in South Africa. Geogr. J. 2007, 173, 26-42. [CrossRef]

50. Lent, P.C.; Mupakati, G. The view from above: A history of land use in Guquka and Koloni, $1938-1996$. In Livelihoods and Landscapes: The People of Guquka and Koloni and Their Resources; Hebinck, P., Lent, P.C., Eds.; Brill: Leiden, The Netherlands, 2007; pp. 165-180. ISBN 9789004161696.

51. Connor, T.; Mtwana, N. Vestige garden production and deagrarianization in three villages in the Eastern Cape, South Africa. S. Afr. Geogr. J. 2018, 100, 82-103. [CrossRef]

52. Manyevere, A.; Muchaonyerwa, P. Farmers' perspectives with regard to crop production: An analysis of Nkonkobe Municipality, South Africa. J. Agric. Rural Dev. Trop. 2014, 115, 41-53. 
53. De la Hey, M.; Beinart, W. Why have South African smallholders largely abandoned arable production in fields? A case study. J. South. Afr. Stud. 2017, 43, 753-770. [CrossRef]

54. Meyfroidt, P. Approaches and terminology for causal analysis in land systems science. J. Land Use Sci. 2016, 11, 501-522. [CrossRef]

55. Mucina, L.; Rutherford, M.C. The Vegetation of South Africa, Lesotho and Swaziland; South African National Biodiversity Institute: Pretoria, South Africa, 2006.

56. Johnson, M.R.; Anhaeusser, C.R.; Thomas, R.J. The Geology of South Africa; Council for GeoScience: Johannesburg, South Africa, 2006.

57. Department for International Development. Sustainable Livelihoods Guidance Sheets; DFID: London, UK, 1999. Available online: http:/ / www.livelihoodscentre.org/documents/20720/100145/Sustainable+livelihoods+ guidance+sheets / 8f35b59f-8207-43fc-8b99-df75d3000e86 (accessed on 28 August 2018).

58. Environmental Systems Research Institute (ESRI). ArcGIS Desktop (Version 10.3.1); Environmental Systems Research Institute: Redlands, CA, USA, 2015.

59. R Core Team. R: A Language and Environment for Statistical Computing; R Foundation for Statistical Computing: Vienna, Austria, 2018; Available online: https:/ / www.R-project.org/ (accessed on 6 July 2018).

60. McAllister, P.A. Reversing the effects of "Betterment Planning" in South Africa's black rural areas. Afr. Insight 1991, 21, 116-119.

61. Matsika, R. The Spatio-Temporal Dynamics of Woody Biomass Supply and Demand in Response to Human Utilisation in an African Savanna Woodland. Ph.D. Thesis, University of the Witwatersrand, Johannesburg, South Africa, 2012.

62. Lidzhegu, Z.; Palamuleni, L.G. Land use and land cover change as a consequence of the South African land reform program: A remote sensing approach. J. Food Agric. Environ. 2012, 10, 1441-1447.

63. Ainslie, A. Cattle ownership and production in the communal areas of the Eastern Cape, South Africa. Programme for Land and Agrarian Studies, University of the Western Cape, 2002. Research report no. 10. Available online: http:/ / www.plaas.org.za/sites/default/files/publications-pdf/RR10.pdf (accessed on 29 August 2018).

64. Hebinck, P. De-/re-agrarianisation: Global perspectives. J. Rural Stud. 2018, 61, 227-235. [CrossRef]

65. Li, T.M. Exit from agriculture: A step forward or a step backward for the rural poor? J. Peasant Stud. 2009, 36, 629-636. [CrossRef]

66. Lambin, E.F.; Meyfroidt, P. Global land use change, economic globalization, and the looming land scarcity. Proc. Natl. Acad. Sci. USA 2011, 108, 3465-3472. [CrossRef] [PubMed]

67. Laughlin, B.O.; Bernstein, H.; Cousins, B.; Peters, P.E. Agrarian change, rural poverty and land reform in South Africa since 1994. J. Agrar. Chang. 2013, 13, 1-15. [CrossRef]

68. Conway, D.; van Garderen, E.A.; Deryng, D.; Dorling, S.; Krueger, T.; Landman, W.; Lankford, B.; Lebek, K.; Osborn, T.; Ringler, C.; et al. Climate and southern Africa's water-energy-food nexus. Nat. Clim. Chang. 2015, 5, 837-846. [CrossRef]

69. Archer, E.R.M.; Landman, W.A.; Tadross, M.A.; Malherbe, J.; Weepener, H.; Maluleke, P.; Marumbwa, F.M. Understanding the evolution of the 2014-2016 summer rainfall seasons in southern Africa: Key lessons. Clim. Risk Manag. 2017, 16, 22-28. [CrossRef]

70. Department of Water Affairs and Forestry. Water Resources of the Republic of South Africa; DWAF: Pretoria, South Africa, 1986; Available online: http://edmc1.dwaf.gov.za/dwaf/rain/about.htm (accessed on 19 September 2018).

71. Hahn, N. An historic account of the extinct high rainfall grasslands of the Soutpansberg, South Africa. Trans. R. Soc. S. Afr. 2018, 73, 20-32. [CrossRef]

72. Skowno, A.L.; Thompson, M.W.; Hiestermann, J.; Ripley, B.; West, A.G.; Bond, W.J. Woodland expansion in South African grassy biomes based on satellite observations (1990-2013): General patterns and potential drivers. Glob. Chang. Biol. 2017, 23, 2358-2369. [CrossRef] [PubMed]

73. Buitenwerf, R.; Bond, W.J.; Stevens, N.; Trollope, W.S.W. Increased tree densities in South African savannas: $>50$ years of data suggests $\mathrm{CO}_{2}$ as a driver. Glob. Chang. Biol. 2012, 18, 675-684. [CrossRef]

74. Stevens, N.; Lehmann, C.E.R.; Murphy, B.P.; Durigan, G. Savanna woody encroachment is widespread across three continents. Glob. Chang. Biol. 2017, 23, 235-244. [CrossRef] [PubMed] 
75. Wigley, B.J.; Bond, W.J.; Hoffman, M.T. Bush encroachment under different land use practices in a mesic south African savanna. Afr. J. Ecol. 2009, 47, 62-70. [CrossRef]

76. Aliber, M.; Hart, T.G.B. Should subsistence agriculture be supported as a strategy to address rural food insecurity? Agrekon 2009, 48, 434-458. [CrossRef]

77. Van Averbeke, W.; Bennett, J. Local governance and institutions. In Livelihoods and Landscapes: The People of Guquka and Koloni and Their Resources; Hebinck, P., Lent, P.C., Eds.; Brill: Leiden, The Netherlands, 2007; pp. 139-164. ISBN 9789004161696.

(c) (2)

(C) 2018 by the authors. Licensee MDPI, Basel, Switzerland. This article is an open access article distributed under the terms and conditions of the Creative Commons Attribution (CC BY) license (http:/ / creativecommons.org/licenses/by/4.0/). 